Review

\title{
New therapeutic targets for hepatic fibrosis in the integrin family, $\alpha 8 \beta 1$ and $\alpha 11 \beta 1$, induced specifically on activated stellate cells
}

\author{
Yasuyuki Yokosaki ${ }^{1 *}$, Norihisa Nishimichi $^{1}$ \\ ${ }^{1}$ Integrin-Matrix Biomedical Science, Translational Research Center, Hiroshima University, 1-2-3, Kasumi, \\ Minami-ku, Hiroshima, Japan, 734-8551; yokosaki@hiroshima-u.ac.jp \\ * Correspondence: yokosaki@hiroshima-u.ac.jp; Tel.: +81-82-257-1523
}

\begin{abstract}
Huge effort has been devoted to developing drugs targeting integrins over 30 years, because of the primary roles of integrins in the cell-matrix milieu. Five $\alpha v$-containing integrins, in the 24 family members, have been a central target of fibrosis. Currently, a small molecule against $\alpha v \beta 1$ is undergoing a clinical trial for NASH-associated fibrosis as a rare reagent aiming at fibrogenesis. Latent TGF $\beta$ activation, a distinct talent of $\alpha \mathrm{v}$ integrins, has been intriguing as therapeutic target. None of the $\alpha \mathrm{v}$-integrin inhibitors, however, has been in the clinical market. $\alpha \mathrm{v}$-integrins commonly recognize an Arg-GlyAsp (RGD) sequence, and thus the pharmacophore of inhibitors for the 5-integrins is based on the same RGD structure. The RGD preference of the integrins, at the same time, dilutes ligand specificity, as the 5-integrins share ligands containing RGD sequence such as fibronectin. With the inherent little specificity in both drugs and targets, "disease specificity" has become less important for the inhibitors than blocking as many $\alpha \mathrm{v}$-integrins. In fact, an almighty inhibitor for $\alpha v$-integrins, pan- $\alpha \mathrm{v}$, was in a clinical trial. On the contrary, approved integrin inhibitors are all specific to target integrins, which are expressed in cell-type specific manner: $\alpha \operatorname{IIb} \beta 3$ on platelets, $\alpha 4 \beta 1, \alpha 4 \beta 7$ and $\alpha \mathrm{L} \beta 2$ on leukocytes. Herein, "disease specific" integrins would serve as attractive targets. $\alpha 8 \beta 1$ and $\alpha 11 \beta 1$ are selectively expressed in hepatic stellate cells (HSCs) and distinctively induced upon culture activation. The exceptional specificity to activated HSCs reflects rather "pathology specific" nature of these new integrins. The monoclonal antibodies against $\alpha 8 \beta 1$ and $\alpha 11 \beta 1$ in preclinical examinations may illuminate the road to the first medical reagents.
\end{abstract}

Keywords: Fibrosis; Integrin; TGF $\beta$; Therapeutic target; Drug; Inhibitor; Monoclonal antibody, $\alpha 8 \beta 1, \alpha 11 \beta 1$, Hepatic stellate cell

\section{Introduction}

Liver fibrosis, also known as cirrhosis, is an intractable disease with high morbidity. There is a serious unmet medical need because no availability of drugs in concert with increasing incidence of non-alcoholic steatohepatitis (NASH)-associated liver fibrosis, i.e., 2 million deaths per year in the world [1-3]. Drugs for NASH-associated fibrosis are aiming at processes of steatosis/hepatitis and following fibrogenesis. Currently, most drugs in clinical trials are the former and the latter are limited especially after simtuzumab (anti-LOXL2) [4] and seronsertive (ASK-1 inhibitor) [5] fell in phase II and III, respectively. In this situation, integrin inhibitors have an emerging therapeutic opportunity in fibrosis [6]. Integrins are a receptor for matrix proteins that essentially consists of fibrosis tissues, and some integrins show activation potential for latent-TGF $\beta$ [7]. In fact, antagonists for $\alpha v \beta 1[8]$ and $\alpha v \beta 6[9,10]$ showed considerable inhibition in experimental animal models for liver, lung, and kidney fibrosis. Encouraged by the discovery of the TGF $\beta$ activation in 1999, pharmacological enthusiasm appears to converge into $\alpha \mathrm{v}$-containing integrins. However, many other members of the integrin family have not been examined each for aptitude to the therapeutic target and no reagents against $\alpha \mathrm{v}$ - 
integrins has been approved for fibrosis and other diseases. We revisit the developmental history of $\alpha \mathrm{v}$-inhibitors, and show alternative new integrins, which contrastingly to $\alpha v$-integrins exhibit pathology-specific expression in fibrosis, $\alpha 8 \beta 1$ [11] and $\alpha 11 \beta 1$ [12].

\section{Leading three players in fibrosis are each related to integrins}

Tissue fibrosis is substantially characterized by deposition of excessive extracellular matrix proteins [13]. The matrix proteins are secreted from activated fibroblasts/myofibroblasts [14]. The fibroblast activation and differentiation to myofibroblast are regulated by TGF $\beta$ [15]. Matrix proteins, fibroblasts, and TGF $\beta$, these 3 diverse players in fibrosis, are each functionally dependent on integrins to play their role in development of fibrosis. Integrins are committed as a sensor for the cell-matrix environment [16] [17], a signaling receptor of fibroblasts [18,19], and an activator of the latent TGF $\beta$ complex [20].

Integrins are a family of cell surface $\alpha$ and $\beta$ heterodimeric receptors for various extracellular matrix proteins. There are $18 \alpha$ and $8 \beta$ subunits that form 24 heterodimers. Cell adhesion by engaging with matrix proteins or cell surface immunoglobulin superfamily members, including ICAM-1 and VCAM-1, is the classical role of integrins [21], which is typically illustrated by hematopoietic integrins to adhere to vascular endothelial cells [22]. As a signaling receptor, integrins mediate fundamental cellular behavior such as cell migration, proliferation, or survival [23]. There are many matrix protein species, which are recognized by multiple integrins. One integrin engages with multiple matrix proteins and one matrix protein interacts with multiple integrins. Ligand repertoire of each integrin thus overlaps one another but, of note, the repertoires of each of 24-integrins are unique. Tissues resident cells, such as epithelial and mesenchymal cells, recognize their matrix environment through integrin receptors and integrins are thus a sensor for the cellular environment including tissue injury. In healthy tissues, integrin plays a role in tissue homeostasis to keep tissue integrity, for example epithelial cells know their position on the basement membrane by recognizing signals from components of the basement membrane such as laminins and collagen type IV via integrin receptors (Figure 1). Once the basement membrane is injured, however, cells notice changes in underlying matrix proteins to those normally present in the subepithelial tissue, like collagen type I and

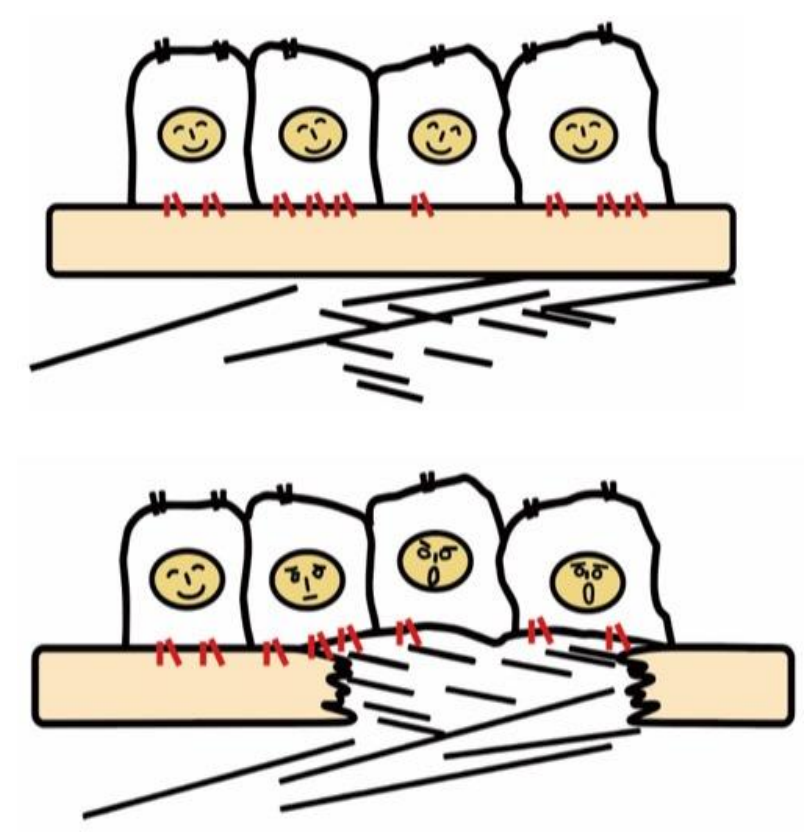

Figure 1. Recognition of tissue injury by epithelial cells via integrin receptors. At the healthy tissue (upper panel), epithelial cells know their peaceful circumstance recognizing components of the basement membrane such as laminin via integrins (red). Upon tissue injury, cells recognize contact with unusual matrix proteins such as collagen type I and fibronectin, which are normally in sub epithelium, and notice the emergent condition.

fibronectin. The recognition of tissue injury by integrin is the case in interstitial cells including fibroblasts. A primary biological role of otherwise quiet fibroblasts is to watch on, 
migrate, and repair tissue injury, secreting matrix proteins [24] and the recognition for the tissue architecture could be an initiation for tissue repair. In these contexts, integrins have been predicted to play a vital role in development of fibrosis. However, the close relationship of integrins with TGF $\beta$ was not predicted until the discovery.

\section{Latent TGF $\beta$ activation by integrins}

The fact that integrin controls TGF $\beta$, the master regulator of fibrosis [25], is one of the strongest evidences for the commitment of integrins to fibrosis. In 1999, integrin $\beta 6$ subunit knockout mice (lacking integrin $\alpha v \beta 6$ heterodimer) were found to be protected against bleomycin induced pulmonary fibrosis [26]. The $\beta 6$-knockout mice were previously found infiltrated with inflammatory cells in the lungs by bronchoalveolar lavage and were thought to exhibit exaggerated lung fibrosis by bleomycin [27]. This seemingly contradictory result was resolved by the discovery, $\alpha \mathrm{v} \beta 6$ mediated-TGF $\beta$ activation. Due to anti-inflammatory and pro-fibrotic bilateral nature of TGF $\beta$, lack of TGF $\beta$ activation in the $\beta 6$-knockout lead to both the inflammation and the protection from fibrosis. Unlike to many other cytokines, TGF $\beta$ is stored in the matrix milieu encapsulated with pro-domain of the TGF $\beta$ protein as an inactive homodimer (Figure 2), so called latency associated peptide (LAP). This manner of storage allows TGF $\beta$ to act at once on demand without de novo protein synthesis. How matured TGF $\beta$ is released form pro-TGF $\beta$ was in long controversy and the discovery of a regulatory system was a big innovatin to understand how interstitial milieu is regulated to be fibrosis controlled.

There is an RGD (Arg-Gly-Asp) tripeptide, that $\alpha \mathrm{v}$-containing and other integrins preferentially bind (Figure 2). Binding of cell surface $\alpha v \beta 6$ to the RGD in pro-TGF $\beta$ complex was found to elicit tensile force with contraction of the $\alpha \mathrm{v} \beta 6$-expressing cells, as the other end of the complex is anchored to latent transforming growth factor $\beta$ binding protein (LTBP) cross-linked to the extracellular milieu [28]. Following release from the complex, TGF $\beta$ is allowed to bind to its receptors. This is the process so called "TGF $\beta$ activation". This discovery owes much to a bioassay, where luciferase TGF $\beta$ signal reporter cells and $\beta 6$-transfected cells are co-cultured. None of the biological roles of integrins may have been more attractive for these 2 decades.

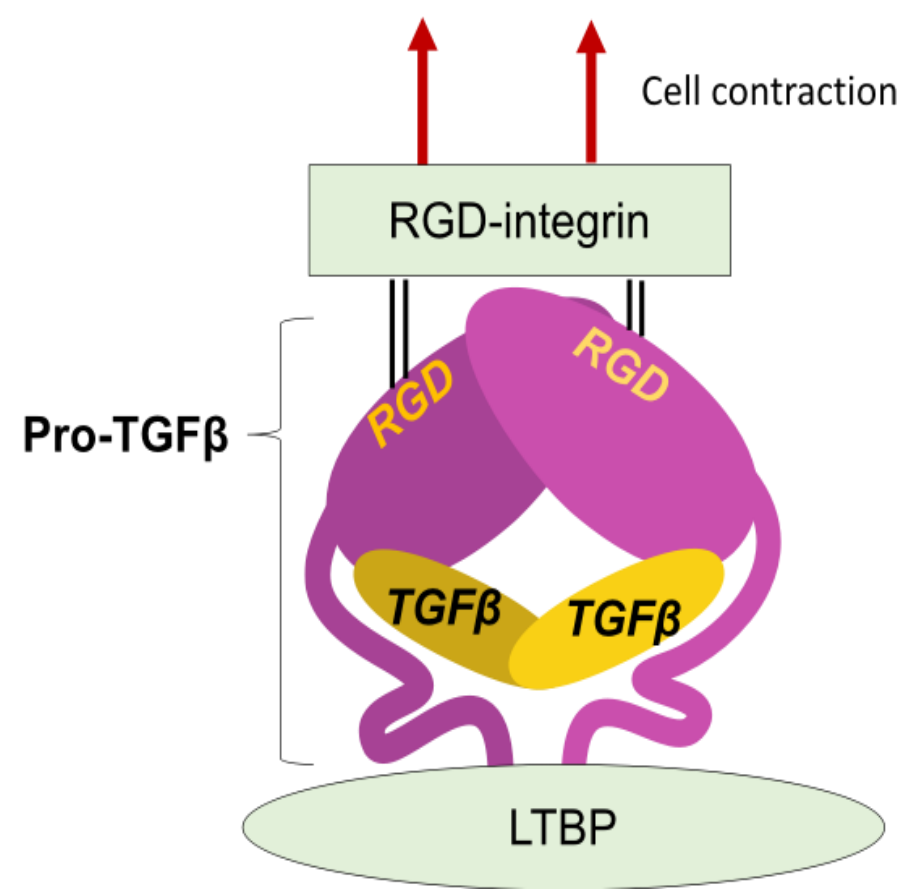

Figure 2. Integrin mediated TGF $\beta$ activation. TGF $\beta$ is stored in the extracellular milieu anchoring to LTBP that is fixed to matrix proteins, as a pro-protein, also termed as LAP. The pro-TGF $\beta$ protein forms homodimer holding TGF $\beta$ by the pro-domains. There is a RGD sequence in the pro-domain. To release TGF $\beta$, RGD-recognizing integrins binds to the RGD sequences and pro-domains are removed from the matured TGF $\beta$ by cellular tensile force initiated by contraction of the cell expressing the integrins. 


\section{Trends of target-integrins for fibrosis}

An RGD-tripeptide is the first amino acid sequence found as a motif that integrins recognizes [29] and is present in many matrix proteins such as fibronectin, vitronectin, and tenascin-C. It is an RGD-peptide that helped the discovery of the first heterodimer by eluting a fibronectin affinity column in 1985 [30]. As many as 8 of 24 members of the integrin family recognize RGD (Figure 3) including all of $5 \alpha \mathrm{v}$-integrins. The RGD has been a keyword in integrin mediated matrix biology. It seems, therefore, natural that an RGD-based pharmacophore has been central to design integrin inhibitors. In addition, expectations for inhibitors of $\alpha v \beta 3$ [31] and $\alpha v \beta 5$ [17][23] [32] [33] as anticancer agent due to their angiogenic potential raised the prospect of RGD-peptide and boosted the pharmacological enthusiasm for the medical drugs [7].

Currently, there are three therapeutics venture companies in US that exclusively targeting the integrin family and reached clinical trials [6]. Two of these companies have been invested over \$200 M from pharmaceutical companies including Novartis, AbbVie, in total and both listed on NASDAQ after 5 years of foundation. Morphic targets each $\alpha v \beta 1$ and $\alpha \mathrm{v} \beta 6$ and Pliant developed dual inhibitor of $\alpha \mathrm{v} \beta 1 / \alpha \mathrm{v} \beta 6$ for idiopathic pulmonary fibrosis [34] and a selective inhibitor on $\alpha v \beta 1$ for NASH-associated fibrosis. The other company Indalo brought the pan- $\alpha \mathrm{v}$ into a clinical trial. These concentrated developments on anti- $\alpha v$-inhibitors are based on many animal experiments and in vitro mechanistic studies, especially $\alpha v \beta 6$. A profibrotic role of $\alpha v \beta 6$ and an anti-fibrotic effect of the anti- $\alpha v \beta 1$ antagonists have been described in lung [9] [10], biliary [35], and kidney fibrosis [36] [37]. Anti-fibrotic treatment targeting $\alpha v \beta 6$ has been effective across organs. However, expression of $\beta 6$ subunit is restricted to the epithelial cells, not central to fibrosis, and the profibrotic role was found irrelevant to some fibrosis models such as $\mathrm{CCl}_{4}$-induced liver fibrosis [35], where fibrosis develops in distance from epithelium. In addition, the pro-TGF $\beta$ activation was found to be performed by any of the other $\alpha \mathrm{v}$-integrins, $\alpha v \beta 1, \alpha v \beta 3, \alpha v \beta 5$ and $\alpha v \beta 8$, [38], [39] [40] [41] depending on conditions. To explore further profibrotic effects of the $\alpha \mathrm{v}$-integrins, first, Itgav was deleted selectively in myofibroblasts in $p d g f r b$-Cre driven conditional $\alpha \mathrm{v}$-knockout mice [42]. The mice lacking all myofibroblast $\alpha \mathrm{v}$-integrins were protected from liver fibrosis. Next, to determine which integrin was important to fibrosis, individual integrins were deleted for $\alpha v \beta 3, \alpha v \beta 5, \alpha v \beta 6$

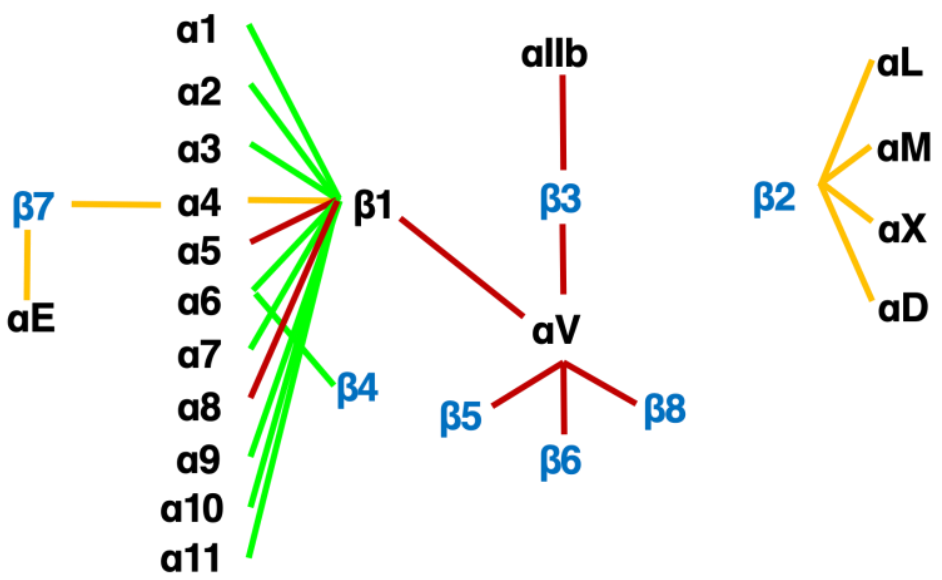

Figure 3. The integrin family. Twenty-four heterodimers and the combinations of $18 \alpha$ and $8 \beta$ subunits are indicated. Eight RGDrecognizing integrins are paired with red lines. Orange lines indicate leukocyte integrins. An alternative name for $\alpha \mathrm{IIb} \beta 3$ is GPIIb/IIIa, and for $\alpha \mathrm{L} \beta 2$ are LFA1 and CD11a/18.

(global) and $\alpha v \beta 8$ (HSC selective), but no protection was found. Therefore, either a combinatory effect of the $\alpha v$-integrins or an independent effect of $\alpha v \beta 1$ (not deleted due to technical limitation) was hypothesized to drive fibrosis. Shortly, a specific small molecule blockade against $\alpha v \beta 1, \mathrm{C} 8$, was developed and showed an excellent inhibitory effect on murine fibrosis models in multiple organs [8], despite off target effects of C8 on $\alpha 4 \beta 1$ 
found later [43]. The above history of RGD peptide starting from the use in the elution buffer, and the established pharmacophore may explain why general interests in integrininhibitors converge on $\alpha v$-integrins. Inhibitors of integrins $\alpha v \beta 1$ and $\alpha v \beta 6$ is the leading pack in 2021[6].

\section{What the history of $\alpha v$-integrin inhibitors tells us}

$\alpha v$-integrins activate TGF $\beta$ and protect against fibrosis when deleted. Nevertheless, no approved $\alpha \mathrm{v}$-inhibitor for fibrosis and other diseases is in the clinic, despite drugs against integrins, $\alpha \operatorname{Ilb} \beta 3$ [44], $\alpha 4 \beta 1$ [45], $\alpha 4 \beta 7$ [46], and $\alpha \mathrm{L} \beta 2$ [47] [48] are making big market [6]. It has been difficult to give specificity to a small molecule inhibitor to individual $\alpha v$-integrins, with the same pharmacophore shared. The initial $\alpha v \beta 3$ inhibitor relied rather on the differential expression in cancer endothelial cells than binding specificity. Furthermore, ligand repertoires of $\alpha \mathrm{v}$-integrins overlap one another, thus signals from $\alpha \mathrm{v}$ integrins could be redundant in some respects. Under these inherent non-specific circumstances of $\alpha v$-integirns, an interesting idea is to inhibit pan- $\alpha v$-integrins [49] [50]. This inversion, leaving the specificity in the second, reveals the technical difficulty. The pan- $\alpha \mathrm{v}$ concept may hold true, because always important is the balance of efficacy and toxicity for drug discovery, depending on the medical need. In fact, IDL-2965 [51] underwent the Phase I clinical trial, but we haven't heard progress, yet. In addition, also known for RGDmimetic integrin inhibitor, is a paradoxical signal input [52] [53] [54] by binding to the ligand binding pocket of integrin. Therefore, ligand mimetic inhibitors for $\alpha \mathrm{v}$ and other integrins should be examined for the signal before entering a clinical trial.

Among $\alpha v$-integrins, only $\alpha v \beta 6$ shows preference for ligands, as the binding sequence in pro-TGF $\beta$ is RGDLxxL/I [55] [56]. For $\alpha v \beta 6$, target specific inhibitor has been obtained [57]. On the other hand, $\alpha v \beta 1$ [58] [59] is a peculiar integrin in terms of the combination of the subunits, both of which are promiscuous, and most cells store a considerable amount of $\alpha \mathrm{v}$ and $\beta 1$ proteins in the cytoplasm to form various heterodimers. However, $\alpha \mathrm{v}$ and $\beta 1$ do not always form the heterodimer in all cells, by unknown mechanisms. Unlike most other integrins, expression of either of the subunits does not identify the heterodimer, and there is no $\mathrm{mAb}$ or labeling reagent that binds to both subunits together. It is, therefore, impossible to define the site of $\alpha \mathrm{v} \beta 1$ accumulation by immunohistochemistry in the fibrotic and healthy tissues. What if $\alpha v \beta 1$ is concentrated in liver fibrosis? The $\alpha v \beta 1$ selective compound, PLN-1474, or others [60] may be closest to the goal, otherwise the pharmacokinetics and pharmacodynamics may need to be analyzed carefully to avoid possible off target effects. Alternatively, $\alpha v \beta 6$ is a principal integrin to activate TGF $\beta$ in epithelial cells, which could be a disease-specific integrin if upregulated in epithelial cells selectively in fibrosis tissue. Progress of these drugs in clinical trials holds a key to future direction of the development of integrin inhibitors.

Specificity to the target is the fundamental critical requirement for molecular target drugs. It is difficult, however, to obtain the specificity for the inhibitors against $\alpha v$-integrins. The absence of the drugs in the clinic may reflect the significance of the specificity.

\section{Disease specific integrins}

Integrins $\alpha v \beta 6$ and $\alpha v \beta 1$ are leading targets for fibrosis, but holds concerns such as epithelial cell restricted expression of $\alpha \mathrm{v} \beta 6$ and unclear systemic distribution of $\alpha \mathrm{v} \beta 1$. Herein, one should be aware that there are 19 non- $\alpha \mathrm{v}$ containing integrins. Most of the non- $\alpha \mathrm{v}$ integrins, excluding leukocyte and platelet integrins, play similar biological roles with $\alpha v$-integrins in view of cell adhesion, tissue integrity and tissue repair as matrix protein receptors. In addition, three of the integrins, $\alpha \operatorname{IIb} \beta 3, \alpha 5 \beta 1$ and $\alpha 8 \beta 1$, engage with RGD-containing ligands. It is, therefore, not surprising if some non- $\alpha \mathrm{v}$ integrins play roles in fibrosis comparably or more innately than $\alpha \mathrm{v}$-integrins. Is there any subunit, unlike to $\alpha v$-integrin, that fulfills " disease-specific" expression? Integrin $\alpha 8 \beta 1$, unlike to most other integrins, shows characteristic restricted expression in mesenchymal cells [61]. A comprehensive gene expression data for 150 primary cells from various tissues [62] reveals $\alpha 8$ 
subunit is selectively expressed on fibroblasts (Figure 4) [11]. Only $\alpha 1, \alpha 8$ and $\alpha 11$ subunit in all the $18 \alpha$ and $8 \beta$ subunits of the integrin family show the fibroblast selective pattern, and $\alpha 8$ is most fibroblast selective as shown in Figure 4. Furthermore, the fibroblast-selective expression of $\alpha 8$ is highly upregulated by a stimulus mimicking fibrosis. $\alpha 8$ in hepatic stellate cells (HSCs) either from rat or mouse is significantly induced both at the mRNA and protein levels [11] by culture activation for 14 days (Figure 5). HSCs are known to be activated by in vitro culture as in fibrotic tissue, associated with elevation of fibrosis markers such as $\alpha$-smooth muscle actin ( $\alpha$-SMA). The "pathology-specific" induction of $\alpha 8 \beta 1$ suggests the "pathology-specific" functional property of $\alpha 8 \beta 1$. Interestingly, $\alpha 11$ is also upregulated similarly to $\alpha 8$ by the same culture activation in rat HSCs [63], with a little bit earlier response than $\alpha 8$ (Figure 5). Because collagens are predominant matrix proteins in fibrosis tissues, collagen receptor integrins have been assumed to play some roles in fibrosis. $\alpha 11 \beta 1$ is one of the 4 collagen receptor integrins and, of note, selectively expressed in fibroblasts, just like $\alpha 8 \beta 1$ (Figure. 5). We will refer to the data by us and others for these 2 integrins to evaluate their suitability as therapeutic targets of fibrosis. It appears that backgrounds why these 2 integrins have been unattended is not because of their functional limitation but substantially by the absence of specific inhibitors.

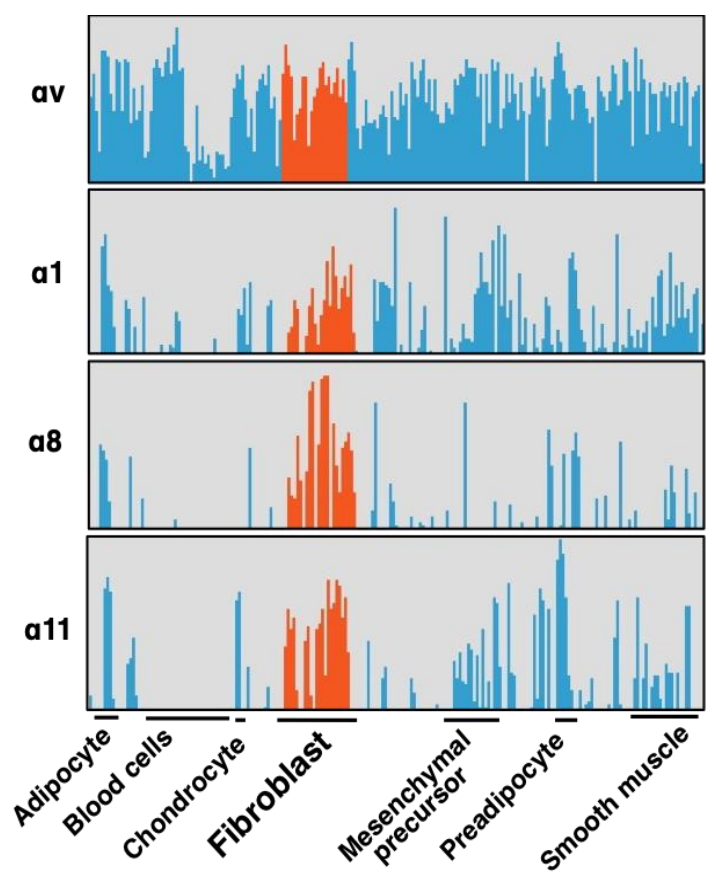

Figure 4. Selective expression of integrin $\alpha$ subunits in fibroblasts. Four $\alpha$ subunits, $\alpha 1, \alpha 8, \alpha 11$ and $\alpha \mathrm{v}$ are upregulated by fibrotic stimulation in HSCs (Figure 5). Expression of the subunits in primary cultures of various cell types are compared focusing on fibroblasts (red). These 4 subunits are expressed in primary cultured fibroblasts from various tissues, and $\alpha 8$ and $\alpha 11$ are in fibroblast selective manner, while $\alpha \mathrm{v}$ subunits are ubiquitously expressed across cell types. $\alpha 1$ is expressed in fibroblasts but also in nonmesenchymal cells such as leukocytes and endothelial cells. $\alpha 8$ and $\alpha 11$ are principally expressed only in mesenchymal cells and $\alpha 8$ is the most specific subunit to fibroblast comparing with $\alpha 11$.

\section{Pathology specific integrin $\alpha 8 \beta 1$ with TGF $\beta$-activating potential}

Three non- $\alpha \mathrm{v}$ integrins, $\alpha \operatorname{Ilb} \beta 3, \alpha 5 \beta 1$ and $\alpha 8 \beta 1$, recognize RGD sequence. $\alpha \operatorname{Ilb} \beta 3$ (GPIIb/IIIa) is exclusively expressed on platelets. $\alpha 5 \beta 1$ interacts with narrow spectrum of ligands and specifically recognize RGDS sequence in the 10th type III repeat of fibronectin and does not recognize RGDL in TGF $\beta$ pro-protein. Integrin $\alpha 8 \beta 1$ more promiscuously engages with RGD in many proteins including, nephronectin, fibronectin, osteopontin, tenascin-C, Mfge- 8 , and, of note pro-TGF $\beta$, protein. 


\subsection{Proposed contribution of $\alpha 8 \beta 1$ to fibrosis and opposing findings}

In 2000, $\alpha 8$ was first reported highly upregulated in lung fibroblasts and HSCs in experimental fibrosis models. Similarly, $\alpha 8$ induction was observed in activated fibroblasts of cardiac fibrosis [64] vascular stenosis [65] , gingival over growth [66]. Due to the prominent upregulation in the lung and liver fibrosis tissues in activated fibroblasts/HSCs, integrin $\alpha 8 \beta 1$ was proposed to be a therapeutic target of fibrosis [67]. However, the expectation was opposed by two findings. TGF $\beta$ activation bioassay using luciferase reporter cells co-cultured with $\alpha 8 \beta 1$-expressing colon cancer cell line, SW480, exhibited negative results, unlike $\alpha \mathrm{v} \beta 6$, despite recognition of RGD by $\alpha 8 \beta 1$ in pro-TGF $\beta$ [68]. Second, expected reduction in fibrosis was not observed in a global Itga8-null mice line in heart [69] and kidney [70] fibrosis.

By our recent experiments, however, $\alpha 8 \beta 1$ activates TGF $\beta$, in a cell type specific manner [11]. $\alpha 8 \beta 1$ on fibroblasts/HSCs activates TGF $\beta$, in contrast, there is no activation by $\alpha 8$-transfected SW480 as previously reported [68]. A tensile force elicited to release TGF $\beta$ between $\alpha \mathrm{v} \beta 6$ and pro-TGF $\beta$ protein was demonstrated in a crystal structure-based 3D model [71]. Cell contractility is an important force for integrin mediated TGF $\beta$ activation. Interestingly, however, $\alpha \mathrm{v} \beta 6$ expressed on SW480 non-contractile cells activates TGF $\beta$, which is disrupted by cytochalasin D [11]. The distinct TGF $\beta$ activation of $\alpha 8 \beta 1$ from $\alpha v \beta 6$ should be more explored for better understanding of the integrin mediated TGF $\beta$ activation.

The other set of conflicting results are from the Itga8-null mouse line. This could be attributed to simply differential effects of $\alpha 8 \beta 1$ by organs. However, a special phenotype of the Itga8 knockout mouse line [72] used in those experiments need to be assessed carefully. The authentic knockout mice line was established in 1997 by crossing Itga $8^{+/}$heterozygous mice and Itga $8^{-/}$mice lacked the whole $\alpha 8$ expression since the fertilization. Interestingly, the line is known for bilateral fatal kidney agenesis, suggesting a role of $\alpha 8 \beta 1$ in nephrogenesis. This effect is corroborated by discovery of recessive mutations of ITGA8 in families with kidney agenesis [73]. Of note, the bilateral agenesis in the $\mathrm{KO}$ line occurs

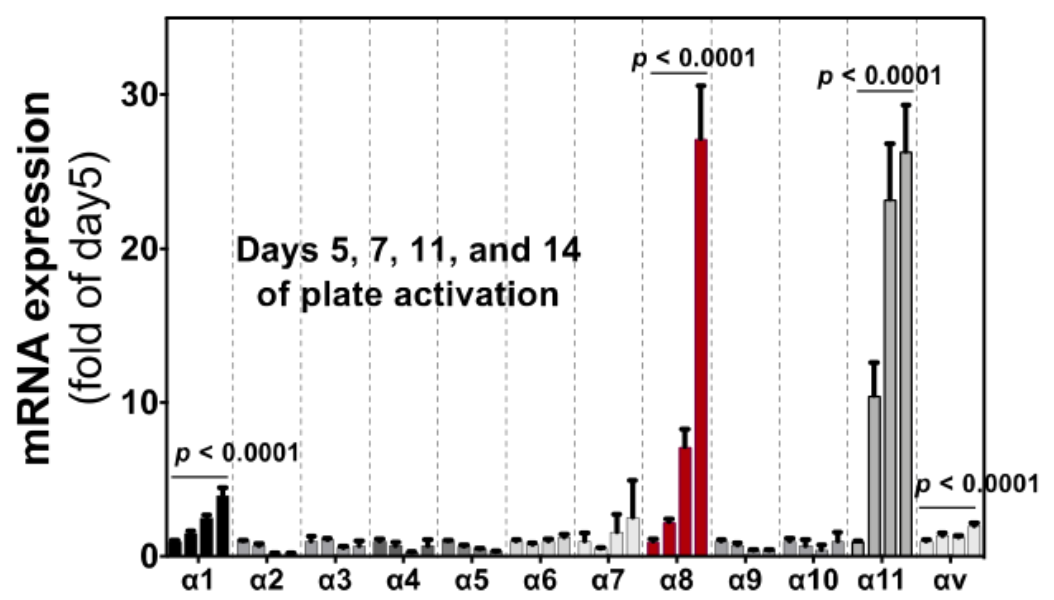

Figure 5. Induction of integrin $\alpha$ subunit in HSCs by culture activation. Bars indicate relative expression of day 5 for $\alpha$ subunits indicated by qPCR. All $\alpha$ subunits that are expressed in tissue cells (excluding cells in the circulation) are evaluated. Each bar represents mean $\pm \mathrm{SE}$, and statistical significances were calculated by ANOVA. (Adopted from Ref. 11)

only in about half of the mice at birth and the other half are survived with one or two kidney(s). The experiments with negative results were performed using the latter half of survived mice, naturally. As the number of kidneys indicates, effects of Itga8-deletion could be different between the fatal and survived groups at least on nephrogenesis. Besides the mechanism for the kidney agenesis, the effect of Itga8-deletion on fibrosis in the survived mice is likely to be compensated by "a stochastic factor" [72]. Such compensation in genetic models is commonly found in zebrafish, where the compensatory expression was not observed in siRNA knockdown model, but in hereditary genetic loss [74]. The 
compensation in zebrafish suggests the same tuning for molecular network in mice and support the idea that the no fibrosis reduction in the Itga8 $/$ mice line were biased by the compensation. In addition, the Itga $8^{--}$mice that survive are fertile and maintained within a Itga8 ${ }^{--}$colony [75], which could concentrate the genetic background related to the stochastic factor. In our Tamoxifen-inducible Itga8 flox/flox; Rosa26-Cre mice, $\alpha 8$ expression is preserved until the beginning of the experiment, kidney development is normal, and importantly liver fibrosis is attenuated [11].

\subsection{Neutralizing $m A b$ for $\alpha 8 \beta 1$}

Most integrin heterodimer receptors have been characterized for the function by use of a specific neutralizing monoclonal antibody ( $\mathrm{mAb}$ ), which is generally obtained following molecular cloning of a subunit and identification of the heterodimer [76]. However, no one has successfully generated the neutralizing $\mathrm{mAb}$ against $\alpha 8 \beta 1$, despite repeated challenges. Therefore, none of evidence for $\alpha 8 \beta 1$-mediated fibrogenesis was provided, although literatures were accumulated describing $\alpha 8$ expression in activated fibroblasts. We, therefore, immunized avian species, chicken, with murine $\alpha 8$ protein and screened with human $\alpha 8 \beta 1$, consequently obtained 3 neutralizing clones [77]. A following epitope mapping revealed that the epitopes of 3 independent $\mathrm{mAb}$ clones overlapped and the shared sequence was totally conserved across mammalian species. The conserved epitope sequence explains why preceded efforts of others in mice, rats, and rabbits have been unsuccessful. The mAb clones, YZ3, YZ5, and YZ26 show potent blocking activity of $\mathrm{IC}_{50}<$ $0.1 \mu \mathrm{g} / \mathrm{ml}$ for cell adhesion, indicating sufficient potency in vitro and in vivo experiments.

\subsection{A role of $\alpha 8 \beta 1$ in fibrosis}

A profibrotic property of $\alpha 8 \beta 1$ was confirmed with the mAb, YZ3 [11]. First, we injected the $\mathrm{mAb}$ in the liver fibrosis models, biliary duct ligation (BDL), $\mathrm{CCl}_{4}$ and clinically relevant NASH-associated model. The fibrosis in the liver was attenuated in all models. Expression of $\alpha 8$ in clinical liver fibrosis was analyzed in 90 patients undergone hepatectomy and elevated in the fibrotic livers compared to F0 controls. Several reports indicate $\alpha 8$ expression is associated with a contractile phenotype of cells such as arrector pili [78] and sensory hair cells [79]. We, therefore, evaluated contribution of $\alpha 8 \beta 1$ to myofibroblast differentiation in HSC culture activation. In three markers upregulated, Acta2, Col1A1 and extra domain-A of fibronectin (EDA), we found Acta2 was reduced by the anti- $\alpha 8 \mathrm{mAb}$. To ensure the $\alpha 8 \beta 1$-dependent upregulation, we plated HSCs on a $\alpha 8 \beta 1$ ligand, nephronectin. This interaction induces nephrogenesis and is biologically active [80]. As expected, the HSCs induced Acta2 expression dose-dependently on nephronectin, which was abrogated by YZ3. The $\alpha 8 \beta 1$-induced myofibroblast differentiation was confirmed by gel contraction assay, where gel contraction induced by nephronectin in collaboration with TGF $\beta$ was inhibited by YZ3. Taken the potentials of myofibroblast differentiation and TGF $\beta$ activation together, $\alpha 8 \beta 1$ is, at least in part, driver of liver fibrosis.

\section{Pathology specific integrin $\alpha 11 \beta 1$, with a property of collagen receptor}

Collagen type I and type III are representative matrix proteins excessively deposit in fibrosis. Changes in collagen density of fibrotic tissue are sensed at least in part by the receptor integrins. There are 4 integrins exclusively serve for collagens [81], $\alpha 1 \beta 1, \alpha 2 \beta 1$, $\alpha 10 \beta 1$ and $\alpha 11 \beta 1$ [82]. We [11] and others [63] found, unlike the other 3 members, $\alpha 11$ is highly induced during culture activation of HSCs (Figure 5) like $\alpha 8$. Tissue distribution of $\alpha 1$ is relatively selective in the mesenchyme and also covers other cell types such as neurons, leukocytes, and end othelial cells (Figure 4). $\alpha 2$ is expressed ubiquitously in epithelial cells, endothelial cells and fibroblasts and mesenchymal stem cells. $\alpha 10 \beta 1$ is a specific receptor for collagen type II that is a predominant constituent for cartilage tissue $(50 \%<)$ and expressed largely in chondrocytes. $\alpha 11$ has been known for its mesenchymal specific 
expression [83]. Comparing to $\alpha 8, \alpha 11$ is expressed more diversely in mesenchyme including chondrocyte, smooth muscle cells, adipocytes, and mesenchymal stem cells (Figure 4).

In all the 24 integrins, $\alpha 11 \beta 1$ and $\alpha 8 \beta 1$ are the only members, that are limited to the mesenchymal cells and preferentially expressed in fibroblasts. Interestingly, both are also the only subunits that are highly induced by culture activation in HSCs [11]. Since $\alpha 11$ is a receptor for collagen at least type I, III, and V [84] [82], and highly induced in fibrosis, it may not be surprising if $\alpha 11$ modulates development of fibrosis. There are accumulating evidence for myofibroblast differentiation by $\alpha 11 \beta 1$ [85] [86] and TGF $\beta$ dependent expression of $\alpha 11$ [87,88]. Furthermore, $\alpha 11$ accumulates in fibroblasts/myofibroblasts in the sites of fibrosis, in murine models of the liver, lung and kidney [12] and human gingival overgrowth [66]. In addition, cardiac fibrosis is induced by over-expression of $\alpha 11$ in mice [89]. This set of data strongly suggested a profibrotic role of $\alpha 11 \beta 1$. As the last piece, direct inhibition of in vivo fibrosis by a specific antagonist for $\alpha 11$ would be of great value. Alternatively, Itga11 knockout mice with inducible ablation could serve as the remaining piece. One or both ways of the target validation have to be done to begin the development of the clinical reagents targeting $\alpha 11 \beta 1$. We have generated a neutralizing $\mathrm{mAb}$ against $\alpha 11 \beta 1$, clone YW33. The mAb specifically recognizes $\alpha 11$ in the 4 -collagen receptor integrins and the recognition is across mammalian species, at least human, mouse and rat. The $\mathrm{mAb}$ inhibits cell adhesion of human $\alpha 11$-transfected $\mathrm{C} 2 \mathrm{C} 12$ cells to collagen type I and type III. Interestingly, the anti- $\alpha 11 \mathrm{mAb}, \mathrm{YW} 33$ also detaches adhered cells from the plates coated with collagen type I and Type III (Figure 6), showing that the mode of action of the inhibition is allosteric. An allosteric inhibition is proposed as an essential requirement for integrin inhibitors [90] as described later.

\section{Future directions for anti-fibrotic integrin inhibitor drugs}

Although many anti-fibrotic drugs targeting integrins and other molecules have suc-

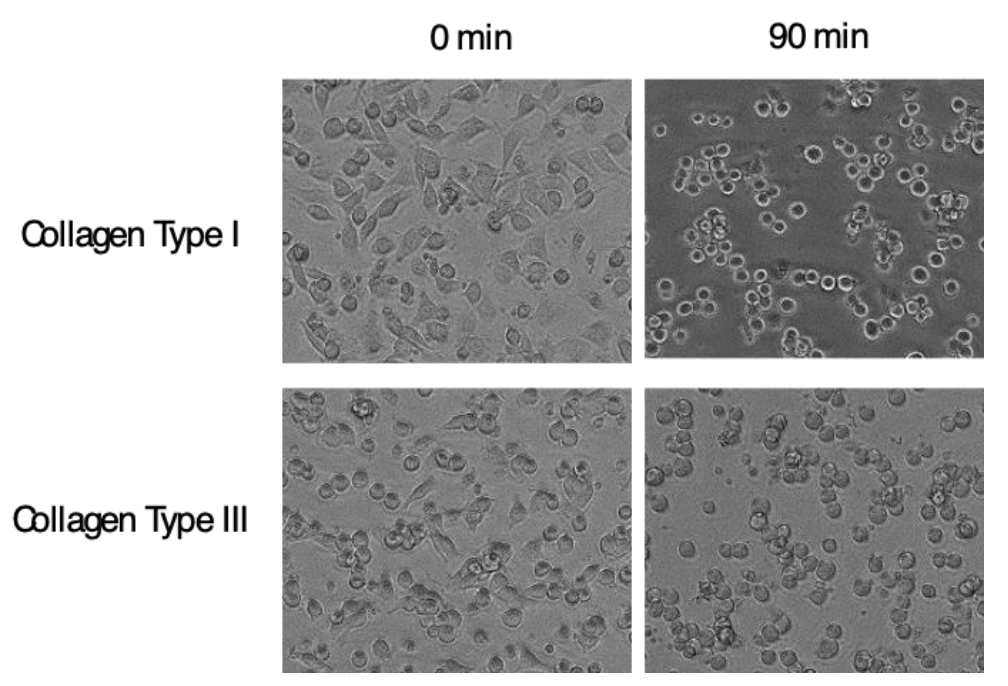

Figure 6. Cell detaching effect of anti- $\alpha 11$ neutralizing $\mathbf{m A b}$. C2C12 cells transfected with Itga11 cDNA were plated on plates coated with indicated collagen. After cells adhered, the anti- $\alpha 11 \mathrm{mAb}, \mathrm{YW} 33$, was added into the culture. Pictures in the left column show cells adhered to the plate, and in the right show cells 90 min after the mAb input. Changes in cell shapes into rounded form indicates weakened attachment of cells.

cessfully undergone preclinical examinations, no drug is in the clinic yet. To break through the clinical trials, we first revisit the preclinical evaluation process focusing on animal experiments modeling human fibrosis, then discus what is the importance of "disease-specificity" in terms of drug discovery based on what leaned from anti- $\alpha v$-inhibitors. Notably, a part of clinical trial is now performed with a combination of drugs. Considering the highly intractable nature of fibrosis with diverse pathological pathways for the 
development, and the absence of effective drugs but many candidate drugs are present, the combination therapy is a reasonable option. Finally, there is a mode of action in inhibitors that is potentially critical to disrupt integrins on duty in the tissues, which may have been paid less attention than needed [91] [90].

\subsection{Evaluation in animal models}

Severity of fibrosis is evaluated relying largely on deposition of collagens in tissue of experimental animals. Several quantification methods of the collagen deposition are established, such as a measurement for hydroxyproline content in the tissue [92] and areas positive for Sirius red or Masson's trichrome staining in histology sections. A collagen amount, due to its physical existence in fibrosis itself as an essential material, is the gold standard of the evaluation. However, because results from preclinical studies do not assure the consequences in clinical trials at all, one might suspect of the value as gold standard in terms of evaluation of drug efficacy in human fibrosis.

Collagen species, components of fibrosis tissue, is the essential and final product of a fibrogenic pathway, which inversely indicates the production is preceded by changes in and around collagen-producing cells. An important focus of evaluation of anti-fibrotic drugs could be derived from such changes in collagen production. Most of clinical fibrosis, including idiopathic pulmonary fibrosis and liver cirrhosis, progress slowly [93] and steadily sometime over decades. In contrast, animal models are set to develop the pathology in several weeks treated with chemicals or surgical procedures evoking exaggerated conditions. Considering the chronicity in human, the dysregulation in the collagen-producing network in the animal models is distinct from the persistent and intractable collagen production in human liver cirrhosis. Is the pathogenesis of collagen deposition in human reflected in the amount of collagen deposition in animals? What we ought to look into animal experiments may not be the consequence after "weeks" but a marker of pathology that leads to chronic deposition. Because minor changes in gene expression, unable to be found when the gold standard was established [94], are detectable and, moreover, cluster of genes that are related to the disorder are estimated by the expression. The platinum standard that reflects future collagen deposition must be the established.

Nevertheless, the collagen reducing effect within the experimental period appear to be indispensable for a go-no-go decision in a preclinical examination. What is the requirements to be the winner? Since the force of collagen accumulation during the animal experiment is far beyond physiological and even pathological regulation in animals, one winner of the decision is a reagent that abrogates collagen production network, and another that affect viability of HSCs, and a looser could be blockades for a specific pathway of collagen production, which generally display effect in a longer period. Considering the chronic nature of human fibrosis, a reagent that inhibit profibrotic process gently but steadily is an important choice, which is contradictory to the acute collagen reducing efficacy required for the decision.

\subsection{Target specificity of integrin inhibitors and pathology specificity of target integrins}

Learned from the developmental history, $\alpha \mathrm{v}$-inhibitors have an inherent nonspecific property. In contrast, the integrin inhibitors already in the clinic, such as abciximab [95], natalizumab [96] [97], vedolizumab [98], and liftegrast [99] commonly exhibit; 1) specific binding to the target, 2) the targets, $\alpha \operatorname{IIb} \beta 3, \alpha 4 \beta 1, \alpha 4 \beta 7$ and $\alpha \mathrm{L} \beta 2$, play a role non-redundantly in the target disease, and are 3 ) expressed on cells important to the pathology, i.e., platelet, and subsets of lymphocytes. These characters of the clinical integrin inhibitors convey that importance of specificity is not only in the drugs but also in the targets. In this respect, for fibrosis an integrin that plays a role specifically in activated fibroblasts/myofibroblast is a hopeful candidate. The functional specificity to the effector cells is achieved simply by the specific expression on the effector cells. The integrins, $\alpha 8 \beta 1$ and $\alpha 11 \beta 1$ are the only integrins that are expressed specifically in fibroblasts and highly induced by the 
stimulation mimicking fibrosis. The unusually demarcated expression must be quite favorable as the clinical integrin inhibitors. In addition, the target specificity of drugs are secured in the neutralizing mAbs. Alternatively, integrins mediating the local TGF $\beta$ activation could satisfies the conditions as the target. As multiple integrins, $\alpha v \beta 1, \alpha v \beta 3, \alpha v \beta 5$, $\alpha v \beta 6, \alpha v \beta 8$ and $\alpha 8 \beta 1$, appear to activate TGF $\beta$ under different circumstances, a requirement for the activation in each integrin could allow pathology specific use of the inhibitors. One such expectation is in the identification of "milieu molecule" [100] [101] [20] required to exert TGF $\beta$ activation.

\subsection{Combination therapy}

There are a lot of diverse pathways to fibrosis, in which where cellular signals influence one another. A single blockade of the pathway in this network could be bypassed through another pathway to develop fibrosis. To evade this issue, clinical trials employing multiple drugs in combination are recently underway. This strategy may also be applied within integrin inhibitors. For example, TGF $\beta$ activation was recently found to be performed by $\alpha 8 \beta 1$, the pan- $\alpha \mathrm{v}$ inhibitor may not completely block TGF $\beta$ activation as expected, depending on the condition for $\alpha 8 \beta 1$ to play the role. Shutting down the $\alpha 8 \beta 1$ mediated pathway could greatly enhance the effects of pan- $\alpha \mathrm{v}$ to inhibit fibrosis. Apart from the pathways, temporally, as progression of clinical liver fibrosis is gradual and persistent, continuous administration of a safe drug in combination with an intermittent administration of potent drug, such as pan- $\alpha \mathrm{v}$.

One more conceivable effective combination is targeting the pathology-specific integrins together. The mAbs for $\alpha 8 \beta 1$ and $\alpha 11 \beta 1$ are both expected to inhibit myofibroblast differentiation [11] [12] [85] through distinct pathways. A signal mediated by $\alpha 8 \beta 1$ is initiated by engagement with nephronectin and $\alpha 11 \beta 1$ by collagens. Because the expression of these integrins is induced in activated HSCs and activated HSCs with myofibroblastic phenotype appears only in fibrotic tissue, the combination is favorable in terms of safety. Once the differentiation is blocked, fibrotic tissue is starved for myofibroblasts, and matrix proteins are no longer newly deposited. This is, therefore, an attractive application of the combination therapy in terms of effects and safety. Of course, a combination of integrin inhibitors with drugs for NASH-associated fibrosis of different mechanism, such as modulators for lipid metabolism, is also an expected option. Since combination therapy is commonly used in the cancer chemotherapy, the strategy appears to be adequate to apply to fibrotic diseases, where no effective drugs in the market.

\subsection{Allosteric inhibition}

A unique feature in the approved integrin inhibitors is that the target integrins are all expressed on circulating cells, i.e., platelets and leukocytes. On the contrary, target integrins of anti-fibrotic drugs are expressed in the tissue cells such as epithelial cells and fibroblasts. Importantly, mode of actions of integrin inhibitors may not be the same by cell type expressing the target. Most of circulating cell integrins are not occupied by ligands but prepared for attaching to vascular cells with the ligand binding pocket open, thorough binding to such as VCAM-1, ICAM-1 and MadCAM-1, while integrins expressed in solid tissues are largely engaged with ligands abundant in the milieu, such as fibronectin, vitronectin, tenascin- $C$, and nephronectin, or laminin and collagen species. In these situations, inhibitor for matrix receptor integrins must dissociate the ligand from integrins to block signal input $[90,91]$, while those for circulating cell integrins just cover the ligandbinding pockets to perform their own tasks. Notably, the dissociation of ligands from cells is achieved by allosteric inhibition, which is clearly illustrated in the action of anti- $\alpha 4$ neutralizing $\mathrm{mAb}$, natalizumab [102]. Allosteric inhibition occurs by binding not directly to the ligand binding pocket but to the site nearby the pocket, as the antibody clashes with the ligand occupying the pocket (Figure 7). Although this mechanism of action needs to be clarified more precisely, there are 2 types of neutralizing $\mathrm{mAb}$ for integrins; one detaches the cell and the other does not. If this is the case, the small molecule inhibitors that 
occupy the ligand binding pocket would have no effect on integrins expressed on tissue cells. Because some of the neutralizing mAbs exhibit allosteric inhibition (Figure 6) depending on the epitope, $\mathrm{mAb}$ may be a prior modality to a small molecule for to really shit down signals from tissue cell integrins. Data demonstrating the requirement for $\mathrm{mAbs}$ to disrupt an interaction of tissue-cell integrin from the ligand are in the literature [102].

\section{Concluding remarks}

Inhibition of integrins attenuates fibrosis in preclinical studies [8] [9] [10] [26] [34] [35] [36] [42] [49] [50] [51] [59][58][103]. Integrins are closely related to leading performers of fibrogenesis, matrix proteins, fibroblasts, and TGF $\beta$, and one of few classes of therapeutic targets of fibrosis, a critical process relating to mortality, in NASH. Because the proTGF $\beta$ activation in situ is so inspiring for design concept of anti-fibrotic drugs, $\alpha \mathrm{v}$ integrins have been a central target for the liver fibrosis, leaving many other integrins behind. However, being no $\alpha \mathrm{v}$ inhibitor drugs in the clinic, more pathology-specific drugs and targets have to be explored. There are stocks of integrins that fulfills the specificity as targets, $\alpha 8 \beta 1$ and $\alpha 11 \beta 1$. Their cell-type specific expression in fibroblasts and by far the highest upregulation in activated fibroblasts $\alpha$ subunits are not found in any other members of the integrin family. Both integrins in fact exhibit profibrotic properties such as myofibroblast differentiation. $\alpha 8 \beta 1$ activates TGF $\beta, \alpha 11 \beta 1$ may as well [104]. Furthermore, inhibition of $\alpha 8 \beta 1$ and inducible genetic deletion of Itga 8 attenuated liver fibrosis. The neutralizing $\mathrm{mAb}$ for each integrin readily allows further validation in vivo and in vitro. Besides the effects, the "pathology specific" induction in the activated HSCs must be a distinct advantage to eliminate off-target adverse effects. Combination therapy with $\alpha \mathrm{v}$ integrin inhibitors may be an expected option.

What is at all the role of integrins that are expressed specifically on activated HSCs? The answer must be within the biological missions of HSCs.

\section{Competitive}

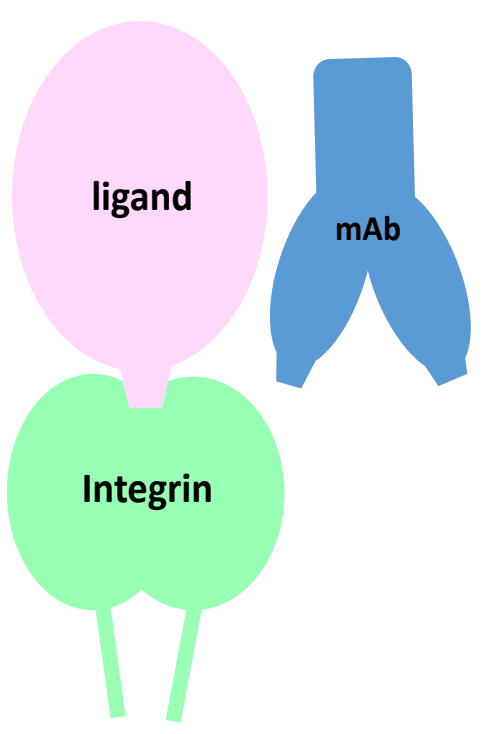

\section{Allosteric}

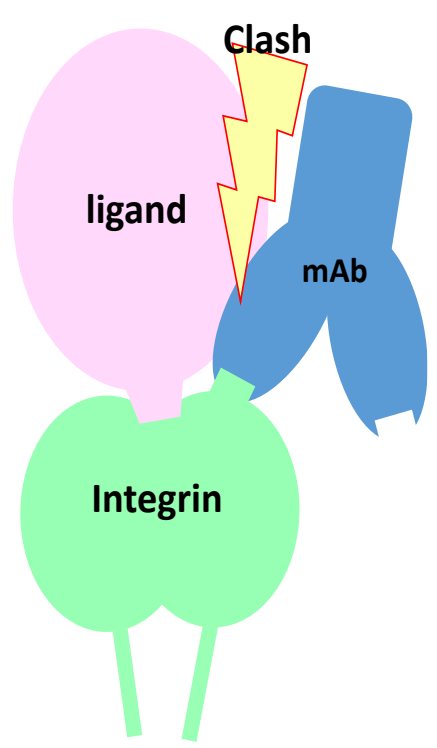

Figure 7. Schematic of mode of actions for neutralizing $\mathrm{mAb}$ with competitive or allosteric inhibition. In both left and right panels, a ligand binds and occupies the ligand binding pocket of an integrin, encompassing the $\alpha$ and $\beta$ subunits of integrin. Left panel: The $\mathrm{mAb}$ competitive inhibitor binds to in and periphery of the ligand binding pocket. When a ligand is already binding to the pocket, the $\mathrm{mAb}$ does not bind or even inaccessible to the epitope. The epitope is completely covered with the ligand. Right panel: The mAb binds to integrin at the epitope that is not close as the competitive inhibitory mAb but localizes closely but around of the ligand binding pocket. The $\mathrm{mAb}$ is allowed to bind to the integrin while clashing with the ligand. 

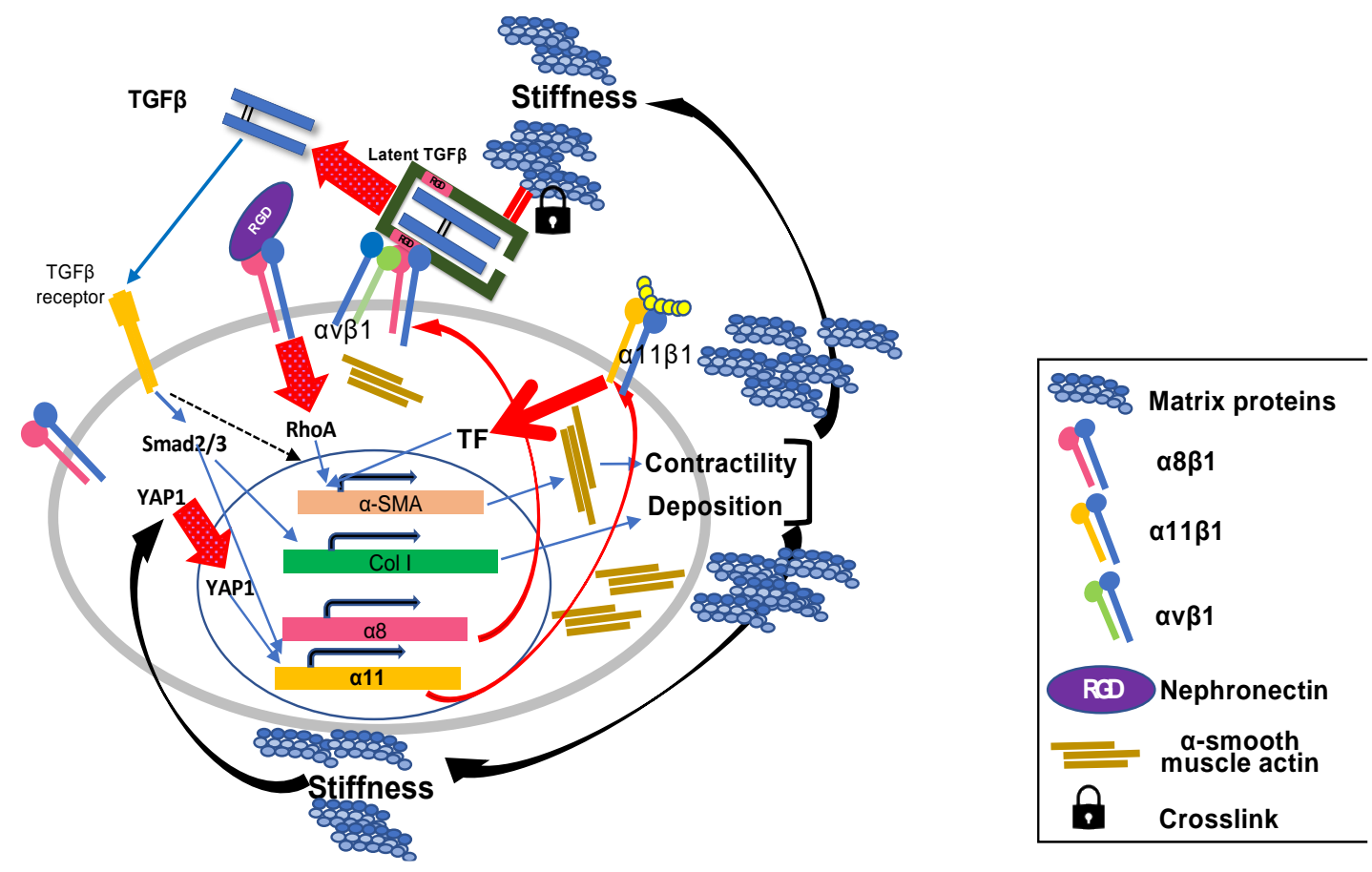

Figure 8. Schematic summary of the roles of the integrins on activated hepatic stellate cells in liver fibrosis. During the fibrogenesis, $\alpha 8$ and $\alpha 11$ subunits are induced on activated HSCs/myofibroblasts. In the fibrotic milieu of the tissue, increased matrix rigidity induces intranuclear translocation of YAP1 and initiates transcription of Itga11 gene. Induced $\alpha 8 \beta 1$ and $\alpha 11 \beta 1$ both promote $\alpha$-SMA expression, actin fiber formation, and cellular contractility upon ligand-engagement with such as nephronectin and collagen type I, respectively. Once HSCs acquire the myofibroblast phenotype, the cells contribute more to TGF $\beta$ activation on their surface through interactions of integrins including $\alpha 8 \beta 1$ and $\alpha \mathrm{v} \beta 1$ with pro-TGF $\beta$ in the surrounding matrix proteins. Released matured TGF $\beta$ binds to its receptor and initiates the Smad signaling cascade. The signal promotes production of matrix proteins containing collagen species from myofibroblasts and $\alpha 11$ expression. Crosstalk between TGF $\beta$-initiated and $\alpha 8 \beta 1-$ and $\alpha 11 \beta 1$-mediated signals cooperatively enhance $\alpha$-SMA expression. These effects by $\alpha 8 \beta 1$ and $\alpha 11 \beta 1$ on HSCs consequently render myofibroblasts highly contractile and productive for collagens and other matrix proteins, which reinforces tissue stiffness to maintain and enhance $\alpha 11$ expression.

Patents: PCT/JP2010/068374 and PCT/JP2013/059368 are patents for the anti- $\alpha 8 \beta 1$ $\mathrm{mAb}$, and PCT/JP2019/008202 is for the anti- $\alpha 11 \beta 1 \mathrm{mAb}$.

Funding: This work was supported in part by Japanese Society for Promotion of Research KAKENHI Grant, Exploratory Research 24659367, Scientific Research (B) 26293174, and Scientific Research (B) 17H04161, by the Grant from Agency for Medical Research and Development (AMED) Japan, Translational Research Program, PreB 20334760, via Okayama University.

Acknowledgments: This work was in part carried out in part at the Analysis Center of Life Science and Animal Care Facility in Hiroshima University.

Conflicts of interest: The authors have no conflicts of interest to declare.

\section{References}

1. Younossi, Z.M.; Koenig, A.B.; Abdelatif, D.; Fazel, Y.; Henry, L.; Wymer, M. Global epidemiology of nonalcoholic fatty liver disease-Meta-analytic assessment of prevalence, incidence, and outcomes. Hepatology 2016, 64, 73-84, doi:10.1002/hep.28431. 
2. $\quad$ Estes, C.; Razavi, H.; Loomba, R.; Younossi, Z.; Sanyal, A.J. Modeling the epidemic of nonalcoholic fatty liver disease demonstrates an exponential increase in burden of disease. Hepatology 2018, 67, 123-133, doi:10.1002/hep.29466.

3. Marcellin, P.; Kutala, B.K. Liver diseases: A major, neglected global public health problem requiring urgent actions and large-scale screening. Liver Int 2018, 38 Suppl 1, 2-6, doi:10.1111/liv.13682.

4. Chen, W.; Yang, A.; Jia, J.; Popov, Y.V.; Schuppan, D.; You, H. Lysyl Oxidase (LOX) Family Members: Rationale and Their Potential as Therapeutic Targets for Liver Fibrosis. Hepatology 2020, 72, 729-741, doi:10.1002/hep.31236.

5. Younossi, Z.M.; Stepanova, M.; Lawitz, E.; Charlton, M.; Loomba, R.; Myers, R.P.; Subramanian, M.; McHutchison, J.G.; Goodman, Z. Improvement of hepatic fibrosis and patient-reported outcomes in non-alcoholic steatohepatitis treated with selonsertib. Liver Int 2018, 38, 1849-1859, doi:10.1111/liv.13706.

6. Slack, R.J.; Macdonald, S.J.F.; Roper, J.A.; Jenkins, R.G.; Hatley, R.J.D. Emerging therapeutic opportunities for integrin inhibitors. Nat Rev Drug Discov 2021, doi:10.1038/s41573-021-00284-4.

7. Kim, K.K.; Sheppard, D.; Chapman, H.A. TGF- $\beta 1$ Signaling and Tissue Fibrosis. Cold Spring Harb Perspect Biol 2017, doi:10.1101/cshperspect.a022293.

8. Reed, N.I.; Jo, H.; Chen, C.; Tsujino, K.; Arnold, T.D.; DeGrado, W.F.; Sheppard, D. The $\alpha v \beta 1$ integrin plays a critical in vivo role in tissue fibrosis. Sci Transl Med 2015, 7, 288 ra279.

9. Horan, G.S.; Wood, S.; Ona, V.; Li, D.J.; Lukashev, M.E.; Weinreb, P.H.; Simon, K.J.; Hahm, K.; Allaire, N.E.; Rinaldi, N.J.; et al. Partial inhibition of integrin $\alpha v \beta 6$ prevents pulmonary fibrosis without exacerbating inflammation. Am J Respir Crit Care Med 2008, 177, 56-65, doi:10.1164/rccm.200706-805OC.

10. Puthawala, K.; Hadjiangelis, N.; Jacoby, S.C.; Bayongan, E.; Zhao, Z.; Yang, Z.; Devitt, M.L.; Horan, G.S.; Weinreb, P.H.; Lukashev, M.E.; et al. Inhibition of integrin $\alpha v \beta 6$, an activator of latent TGF- $\beta$, prevents radiation-induced lung fibrosis. Am J Respir Crit Care Med 2008, 177, 82-90, doi:10.1164/rccm.200706-806OC.

11. Nishimichi, N.; Tsujino, K.; Kanno, K.; Sentani, K.; Kobayashi, T.; Chayama, K.; Sheppard, D.; Yokosaki, Y. Induced hepatic stellate cell integrin, $\alpha 8 \beta 1$, enhances cellular contractility and TGF $\beta$ activity in liver fibrosis. $J$ Pathol 2021, doi:10.1002/path.5618.

12. Bansal, R.; Nakagawa, S.; Yazdani, S.; van Baarlen, J.; Venkatesh, A.; Koh, A.P.; Song, W.M.; Goossens, N.; Watanabe, H.; Beasley, M.B.; et al. Integrin $\alpha 11$ in the regulation of the myofibroblast phenotype: implications for fibrotic diseases. Exp Mol Med 2017, 49, e396, doi:10.1038/emm.2017.213.

13. Schwabe, R.F.; Tabas, I.; Pajvani, U.B. Mechanisms of Fibrosis Development in Nonalcoholic Steatohepatitis. Gastroenterology 2020, 158, 1913-1928, doi:10.1053/j.gastro.2019.11.311.

14. Schuppan, D.; Surabattula, R.; Wang, X.Y. Determinants of fibrosis progression and regression in NASH. J Hepatol 2018, 68, 238-250, doi:10.1016/j.jhep.2017.11.012.

15. Lodyga, M.; Hinz, B. TGF- $\beta 1$ - A truly transforming growth factor in fibrosis and immunity. Semin Cell Dev Biol 2020, 101, 123-139, doi:10.1016/j.semcdb.2019.12.010.

16. Kechagia, J.Z.; Ivaska, J.; Roca-Cusachs, P. Integrins as biomechanical sensors of the microenvironment. Nat Rev Mol Cell Biol 2019, 20, 457-473, doi:10.1038/s41580-019-0134-2.

17. Miranti, C.K.; Brugge, J.S. Sensing the environment: a historical perspective on integrin signal transduction. Nat Cell Biol 2002, 4, 83-90.

18. ffrench-Constant, C.; Colognato, H. Integrins: versatile integrators of extracellular signals. Trends Cell Biol 2004, 14, 678-686, doi:10.1016/j.tcb.2004.10.005.

19. Lynch, M.D.; Watt, F.M. Fibroblast heterogeneity: implications for human disease. The Journal of clinical investigation 2018, 128, 26-35, doi:10.1172/jci93555.

20. Nolte, M.; Margadant, C. Controlling Immunity and Inflammation through Integrin-Dependent Regulation of TGF- $\beta$. Trends in cell biology 2020, 30, 49-59, doi:10.1016/j.tcb.2019.10.002.

21. Hynes, R. Integrins: Versatility, Modulation, and Signaling in Cell Adhesion. Cell 1992, 69, 11-25.

22. Vestweber, D. How leukocytes cross the vascular endothelium. Nat Rev Immunol 2015, 15, 692-704, doi:10.1038/nri3908.

23. Reynolds, L.E.; Wyder, L.; Lively, J.C.; Taverna, D.; Robinson, S.D.; Huang, X.; Sheppard, D.; Hynes, R.O.; Hodivala-Dilke, K.M. Enhanced pathological angiogenesis in mice lacking beta3 integrin or beta3 and beta5 integrins. Nat Med 2002, 8, 27-34, doi:10.1038/nm0102-27.

24. Lemos, D.R.; Duffield, J.S. Tissue-resident mesenchymal stromal cells: Implications for tissue-specific antifibrotic therapies. Sci Transl Med 2018, 10, eaan5174. 
25. Meng, X.M.; Nikolic-Paterson, D.J.; Lan, H.Y. TGF- $\beta$ : the master regulator of fibrosis. Nature reviews. Nephrology 2016, 12, 325-338, doi:10.1038/nrneph.2016.48.

26. Munger, J.S.; Huang, X.; Kawakatsu, H.; Griffiths, M.J.D.; Dalton, S.L.; Wu, J.; Pittet, J.-F.; Kaminski, N.; Garat, C.; Matthay, M.A.; et al. The integrin $\alpha v \beta 6$ binds and activates latent TGF $\beta 1$ : A mechanism for regulating pulmonary inflammation and fibrosis. Cell 1999, 96, 319-328.

27. Huang, X.Z.; Wu, J.F.; Cass, D.; Erle, D.J.; Corry, D.; Young, S.G.; Farese, R.V., Jr.; Sheppard, D. Inactivation of the integrin beta 6 subunit gene reveals a role of epithelial integrins in regulating inflammation in the lung and skin. J Cell Biol 1996, 133, 921-928, doi:10.1083/jcb.133.4.921.

28. Robertson, I.B.; Horiguchi, M.; Zilberberg, L.; Dabovic, B.; Hadjiolova, K.; Rifkin, D.B. Latent TGF- $\beta$-binding proteins. Matrix Biol 2015, 47, 44-53, doi:10.1016/j.matbio.2015.05.005.

29. Ruoslahti, E.; Pierschbacher, M.D. New perspectives in cell adhesion: RGD and integrins. Science 1987, 238, 491-497, doi:10.1126/science.2821619.

30. Pytela, R.; Pierschbacher, M.D.; Ruoslahti, E. Identification and isolation of a $140 \mathrm{kd}$ cell surface glycoprotein with properties expected of a fibronectin receptor. Cell 1985, 40, 191-198.

31. Brooks, P.C.; Montgomery, A.M.; Rosenfeld, M.; Reisfeld, R.A.; Hu, T.; Klier, G.; Cheresh, D.A. Integrin alpha $\mathrm{v}$ beta 3 antagonists promote tumor regression by inducing apoptosis of angiogenic blood vessels. Cell 1994, 79, 1157-1164, doi:10.1016/0092-8674(94)90007-8.

32. Friedlander, M.; Brooks, P.C.; Shaffer, R.W.; Kincaid, C.M.; Varner, J.A.; Cheresh, D.A. Definition of two angiogenic pathways by distinct alpha v integrins. Science 1995, 270, 1500-1502, doi:10.1126/science.270.5241.1500.

33. Sheppard, D. Endothelial integrins and angiogenesis: not so simple anymore. The Journal of clinical investigation 2002, 110, 913-914, doi:10.1172/jci16713.

34. Decaris, M.L.; Schaub, J.R.; Chen, C.; Cha, J.; Lee, G.G.; Rexhepaj, M.; Ho, S.S.; Rao, V.; Marlow, M.M.; Kotak, P.; et al. Dual inhibition of $\alpha \mathrm{v} \beta 6$ and $\alpha \mathrm{v} \beta 1$ reduces fibrogenesis in lung tissue explants from patients with IPF. Respir Res 2021, 22, 265, doi:10.1186/s12931-021-01863-0.

35. Wang, B.; Dolinski, B.M.; Kikuchi, N.; Leone, D.R.; Peters, M.G.; Weinreb, P.H.; Violette, S.M.; Bissell, D.M. Role of $\alpha \mathrm{v} \beta 6$ integrin in acute biliary fibrosis. Hepatology 2007, 46, 1404-1412, doi:10.1002/hep.21849.

36. Ma, L.-J.; Yang, H.; Gaspert, A.; Carlesso, G.; Barty, M.M.; Davidson, J.M.; Sheppard, D.; Fogo, A.B. Transforming Growth Factor- $\beta$-Dependent and -Independent Pathways of Induction of Tubulointerstitial Fibrosis in 36-/- Mice. The American Journal of Pathology 2003, 163, 1261-1273, doi:10.1016/s0002-9440(10)63486-4.

37. Hahm, K.; Lukashev, M.E.; Luo, Y.; Yang, W.J.; Dolinski, B.M.; Weinreb, P.H.; Simon, K.J.; Chun Wang, L.; Leone, D.R.; Lobb, R.R.; et al. Alphav beta6 integrin regulates renal fibrosis and inflammation in Alport mouse. Am J Pathol 2007, 170, 110-125, doi:10.2353/ajpath.2007.060158.

38. Asano, Y.; Ihn, H.; Yamane, K.; Jinnin, M.; Mimura, Y.; Tamaki, K. Involvement of $\alpha v \beta 5$ integrin-mediated activation of latent transforming growth factor beta1 in autocrine TGF- $\beta$ signaling in systemic sclerosis fibroblasts. Arthritis Rheum 2005, 52, 2897-2905, doi:10.1002/art.21246.

39. Crystal, R.G.; Bitterman, P.B.; Mossman, B.; Schwarz, M.I.; Sheppard, D.; Almasy, L.; Chapman, H.A.; Friedman, S.L.; King, T.E., Jr.; Leinwand, L.A.; et al. Future research directions in idiopathic pulmonary fibrosis: summary of a National Heart, Lung, and Blood Institute working group. Am J Respir Crit Care Med 2002, 166, 236-246, doi:10.1164/rccm.2201069.

40. Wipff, P.J.; Rifkin, D.B.; Meister, J.J.; Hinz, B. Myofibroblast contraction activates latent TGF- $\beta 1$ from the extracellular matrix. J Cell Biol 2007, 179, 1311-1323, doi:10.1083/jcb.200704042.

41. Sarrazy, V.; Koehler, A.; Chow, M.L.; Zimina, E.; Li, C.X.; Kato, H.; Caldarone, C.A.; Hinz, B. Integrins $\alpha v \beta 5$ and $\alpha v \beta 3$ promote latent TGF- $\beta 1$ activation by human cardiac fibroblast contraction. Cardiovasc Res 2014, 102, 407-417, doi:10.1093/cvr/cvu053.

42. Henderson, N.C.; Arnold, T.D.; Katamura, Y.; Giacomini, M.M.; Rodriguez, J.D.; McCarty, J.H.; Pellicoro, A.; Raschperger, E.; Betsholtz, C.; Ruminski, P.G.; et al. Targeting of $\alpha \mathrm{v}$ integrin identifies a core molecular pathway that regulates fibrosis in several organs. Nat Med 2013, 19, 1617-1624, doi:10.1038/nm.3282.

43. Wilkinson, A.L.; Barrett, J.W.; Slack, R.J. Pharmacological characterisation of a tool $\alpha v \beta 1$ integrin small molecule RGD-mimetic inhibitor. European journal of pharmacology 2019, 842, 239-247,

doi:10.1016/j.ejphar.2018.10.045.

44. Coller BS; Scudder LE; J, B. Monoclonal antibodies to platelet glycoprotein IIb/IIIa as antithrombotic agents. .

Ann N Y Acad Sci 1991, 614, 193-213. 
45. Li, H.; Shi, F.-H.; Huang, S.-Y.; Zhang, S.-G.; Chen, M.-L. A Review on Clinical Pharmacokinetics, Pharmacodynamics, and Pharmacogenomics of Natalizumab: A Humanized Anti- $\alpha 4$ Integrin Monoclonal Antibody. Curr Drug Metab 2018, 19, 1213-1223, doi:10.2174/1389200219666180427165841.

46. Rai, R.P.; Liu, Y.; Iyer, S.S.; Liu, S.; Gupta, B.; Desai, C.; Kumar, P.; Smith, T.; Singhi, A.D.; Nusrat, A.; et al. Blocking integrin $\alpha 4 \beta 7$-mediated CD4 T cell recruitment to the intestine and liver protects mice from western diet-induced non-alcoholic steatohepatitis. J Hepatol 2020, doi:10.1016/j.jhep.2020.05.047.

47. Gérard, A.; Cope, A.P.; Kemper, C.; Alon, R.; Köchl, R. LFA-1 in T cell priming, differentiation, and effector functions. Trends Immunol 2021, 42, 706-722, doi:10.1016/j.it.2021.06.004.

48. Perez, V.L.; Pflugfelder, S.C.; Zhang, S.; Shojaei, A.; Haque, R. Lifitegrast, a Novel Integrin Antagonist for Treatment of Dry Eye Disease. Ocul Surf 2016, 14, 207-215, doi:10.1016/j.jtos.2016.01.001.

49. Ulmasov, B.; Neuschwander-Tetri, B.A.; Lai, J.; Monastyrskiy, V.; Bhat, T.; Yates, M.P.; Oliva, J.; Prinsen, M.J.; Ruminski, P.G.; Griggs, D.W. Inhibitors of Arg-Gly-Asp-Binding Integrins Reduce Development of Pancreatic Fibrosis in Mice. Cell Mol Gastroenterol Hepatol 2016, 2, 499-518, doi:10.1016/j.jcmgh.2016.03.004.

50. Ulmasov, B.; Noritake, H.; Carmichael, P.; Oshima, K.; Griggs, D.W.; Neuschwander-Tetri, B.A. An Inhibitor of Arginine-Glycine-Aspartate-Binding Integrins Reverses Fibrosis in a Mouse Model of Nonalcoholic Steatohepatitis. Hepatol Commun 2019, 3, 246-261, doi:10.1002/hep4.1298.

51. Kossen, K.; Schaefer, C.; Lim, S.; Michener, M.; Ruminiski, P.; Griggs, D.; Radhakrishnan, R.; Bradford, B.; Seiwert, S. IDL-2965: A Selective, highly-potent, oral Integrin antagonist for IPF. Europan Respiratory Journal 2019, 54, PA5374.

52. Chew, D.P.; Bhatt, D.L.; Sapp, S.; Topol, E.J. Increased Mortality With Oral Platelet Glycoprotein IIb/IIIa Antagonists. A Meta-Analysis of Phase III Multicenter Randomized Trials. Circulation 2001, 103, 201-206.

53. Cox, D.; Brennan, M.; Moran, N. Integrins as therapeutic targets: lessons and opportunities. Nat Rev Drug Discov 2010, 9, 804-820, doi:10.1038/nrd3266.

54. Van Agthoven, J.F.; Xiong, J.P.; Alonso, J.L.; Rui, X.; Adair, B.D.; Goodman, S.L.; Arnaout, M.A. Structural basis for pure antagonism of integrin $\alpha \mathrm{V} \beta 3$ by a high-affinity form of fibronectin. Nat Struct Mol Biol 2014, 21, 383-388, doi:10.1038/nsmb.2797.

55. Dong, X.; Hudson, N.E.; Lu, C.; Springer, T.A. Structural determinants of integrin beta-subunit specificity for latent TGF-beta. Nat Struct Mol Biol 2014, 21, 1091-1096, doi:10.1038/nsmb.2905.

56. Dong, X.; Zhao, B.; Lin, F.Y.; Lu, C.; Rogers, B.N.; Springer, T.A. High integrin $\alpha \mathrm{V} \beta 6$ affinity reached by hybrid domain deletion slows ligand-binding on-rate. Proceedings of the National Academy of Sciences of the United States of America 2018, 115, E1429-e1436, doi:10.1073/pnas.1718662115.

57. Maltsev, O.V.; Marelli, U.K.; Kapp, T.G.; Di Leva, F.S.; Di Maro, S.; Nieberler, M.; Reuning, U.; Schwaiger, M.; Novellino, E.; Marinelli, L.; et al. Stable peptides instead of stapled peptides: Highly potent $\alpha v \beta 6$-selective integrin ligands. Angew Chem Int Ed Engl 2015, doi:10.1002/anie.201508709.

58. Sundaram, A.; Chen, C.; Isik Reed, N.; Liu, S.; Ki Yeon, S.; McIntosh, J.; Tang, Y.Z.; Yang, H.; Adler, M.; Beresis, R.; et al. Dual antagonists of $\alpha 5 \beta 1 / \alpha v \beta 1$ integrin for airway hyperresponsiveness. Bioorg Med Chem Lett 2020, 30, 127578, doi:10.1016/j.bmcl.2020.127578.

59. Han, Z.; Ma, Y.; Cao, G.; Ma, Z.; Chen, R.; Cvijic, M.E.; Cheng, D. Integrin $\alpha$ V $\beta 1$ regulates procollagen I production through a non-canonical transforming growth factor $\beta$ signaling pathway in human hepatic stellate cells. Biochem J 2021, 478, 1689-1703, doi:10.1042/bcj20200749.

60. Hatley, R.J.D.; Barrett, T.N.; Slack, R.J.; Watson, M.E.; Baillache, D.J.; Gruszka, A.; Washio, Y.; Rowedder, J.E.; Pogány, P.; Pal, S.; et al. The Design of Potent, Selective and Drug-Like RGD $\alpha v \beta 1$ Small-Molecule Inhibitors Derived from non-RGD $\alpha 4 \beta 1$ Antagonists. ChemMedChem 2019, 14, 1315-1320, doi:10.1002/cmdc.201900359.

61. Schnapp, L.M.; Breuss, J.M.; Ramos, D.M.; Sheppard, D.; Pytela, R. Sequence and tissue distribution of the human integrin $\alpha 8$ subunit: a $\beta 1$-associated $\alpha$ subunit expressed in smooth muscle cells. J Cell Sci 1995, 108, 537-544.

62. Ono, H.; Ogasawara, O.; Okubo, K.; Bono, H. RefEx, a reference gene expression dataset as a web tool for the functional analysis of genes. Scientific Data 2017, 4, doi:10.1038/sdata.2017.105.

63. Martin, K.; Pritchett, J.; Llewellyn, J.; Mullan, A.F.; Athwal, V.S.; Dobie, R.; Harvey, E.; Zeef, L.; Farrow, S.; Streuli, C.; et al. PAK proteins and YAP-1 signalling downstream of integrin $\beta 1$ in myofibroblasts promote liver fibrosis. Nature communications 2016, 7, 12502, doi:10.1038/ncomms12502. 
64. Thibault, G.; Lacombe, M.-J.; Schnapp, L.M.; Lacasse, A.; Bouzeghrane, F.; Lapalme, G.V. Upregulation of $\alpha 8 \beta 1$-integrin in cardiac fibroblast by angiotensin II and transforming growth factor- 1. Am J Physiol Cell Physiol 2001, 281, C1457-C1467.

65. Zargham, R.; Pepin, J.; Thibault, G. $\alpha 8 \beta 1$ Integrin is up-regulated in the neointima concomitant with late luminal loss after balloon injury. Cardiovasc Pathol 2007, 16, 212-220, doi:10.1016/j.carpath.2007.01.010.

66. Ju, Y.; Huang, L.; Wang, S.; Zhao, S. Transcriptional Analysis Reveals Key Genes in the Pathogenesis of Nifedipine-Induced Gingival Overgrowth. Anal Cell Pathol (Amst) 2020, 2020, 6128341, doi:10.1155/2020/6128341.

67. Levine, D.; Rockey, D.C.; Milner, T.A.; Breuss, J.M.; Fallon, J.T.; Schnapp, L.M. Expression of the Integrin

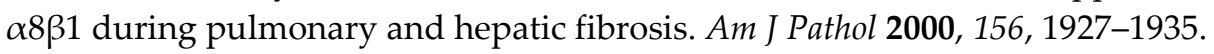

68. Lu, M.; Munger, J.S.; Steadele, M.; Busald, C.; Tellier, M.; Schnapp, L.M. Integrin $\alpha 8 \beta 1$ mediates adhesion to LAP-TGFß1. J Cell Sci 2002, 115, 4641-4648, doi:10.1242/jcs.00145.

69. Hartner, A.; Cordasic, N.; Rascher, W.; Hilgers, K.F. Deletion of the $\alpha 8$ integrin gene does not protect mice from myocardial fibrosis in DOCA hypertension. Am J Hypertens 2009, 22, 92-99, doi:10.1038/ajh.2008.309.

70. Hartner, A.; Menendez-Castro, C.; Cordasic, N.; Marek, I.; Volkert, G.; Klanke, B.; Rascher, W.; Hilgers, K.F. Tubulointerstitial de novo expression of the $\alpha 8$ integrin chain in a rodent model of renal fibrosis--a potential target for anti-fibrotic therapy? PLoS One 2012, 7, e48362, doi:10.1371/journal.pone.0048362.

71. Dong, X.; Zhao, B.; Iacob, R.E.; Zhu, J.; Koksal, A.C.; Lu, C.; Engen, J.R.; Springer, T.A. Force interacts with macromolecular structure in activation of TGF- $\beta$. Nature 2017, 542, 55-59, doi:10.1038/nature21035.

72. Muller, U.; Wang, D.; Denda, S.; Meneses, J.J.; Pedersen, R.A.; Reichardt, L.F. Integrin $\alpha 8 \beta 1$ Is Critically Important for Epithelial-Mesenchymal Interactions during Kidney Morphogenesis. Cell 1997, 88, 603-613.

73. Humbert, C.; Silbermann, F.; Morar, B.; Parisot, M.; Zarhrate, M.; Masson, C.; Tores, F.; Blanchet, P.; Perez, M.J.; Petrov, Y.; et al. Integrin $\alpha 8$ recessive mutations are responsible for bilateral renal agenesis in humans. Am J Hum Genet 2014, 94, 288-294, doi:10.1016/j.ajhg.2013.12.017.

74. Rossi, A.; Kontarakis, Z.; Gerri, C.; Nolte, H.; Holper, S.; Kruger, M.; Stainier, D.Y. Genetic compensation induced by deleterious mutations but not gene knockdowns. Nature 2015, 524, 230-233, doi:10.1038/nature14580.

75. Hartner, A.; Cordasic, N.; Klanke, B.; 1ler, U.M.; Sterzel, R.B.; Hilgers, K.F. The $\alpha 8$ integrin chain affords mechanical stability to the glomerular capillary tuft in hypertensive glomerular disease. Am J Pathol 2002, 160, 861-867.

76. Byron, A.; Humphries, J.D.; Askari, J.A.; Craig, S.E.; Mould, A.P.; Humphries, M.J. Anti-integrin monoclonal antibodies. J Cell Sci 2009, 122, 4009-4011, doi:10.1242/jcs.056770.

77. Nishimichi, N.; Kawashima, N.; Yokosaki, Y. Epitopes in $\alpha 8 \beta 1$ and other RGD-binding integrins delineate classes of integrin-blocking antibodies and major binding loops in $\alpha$ subunits. Scientific reports 2015, 5, 13756, doi:10.1038/srep13756.

78. Fujiwara, H.; Ferreira, M.; Donati, G.; Marciano, D.; Linton, J.; Sato, Y.; Hartner, A.; Sekiguchi, K.; Reichardt, L.; Watt, F. The basement membrane of hair follicle stem cells is a muscle cell niche. Cell 2011, 144, 577-589, doi:10.1016/j.cell.2011.01.014.

79. Evans, A.L.; Muiller, U. Stereocilia defects in the sensory hair cells of the inner ear in mice deficient in integrin $\alpha 8 \beta 1$. Nat Gene 2000, 24, 424-428.

80. Linton, J.M.; Martin, G.R.; Reichardt, L.F. The ECM protein nephronectin promotes kidney development via integrin $\alpha 8 \beta 1$-mediated stimulation of Gdnf expression. Development 2007, 134, 2501-2509, doi:10.1242/dev.005033.

81. Musiime, M.; Chang, J.; Hansen, U.; Kadler, K.E.; Zeltz, C.; Gullberg, D. Collagen Assembly at the Cell Surface: Dogmas Revisited. Cells 2021, 10, doi:10.3390/cells10030662.

82. Zeltz, C.; Gullberg, D. The integrin-collagen connection - a glue for tissue repair? J Cell Sci 2016, 129, 1284, doi:10.1242/jcs.188672.

83. Popova, S.N.; Rodriguez-Sanchez, B.; Liden, A.; Betsholtz, C.; Van Den Bos, T.; Gullberg, D. The mesenchymal $\alpha 11 \beta 1$ integrin attenuates PDGF-BB-stimulated chemotaxis of embryonic fibroblasts on collagens. Dev Biol 2004, 270, 427-442, doi:10.1016/j.ydbio.2004.03.006.

84. Zeltz, C.; Lu, N.; Gullberg, D. Integrin $\alpha 11 \beta 1$ : a major collagen receptor on fibroblastic cells. In I-domain integrins; Advances in Experimental Medicine and Biology 2014; pp. 73-84.

85. Talior-Volodarsky, I.; Connelly, K.A.; Arora, P.D.; Gullberg, D.; McCulloch, C.A. $\alpha 11$ Integrin stimulates myofibroblast differentiation in diabetic cardiomyopathy. Cardiovasc Res 2012, 96, 265-275, doi:10.1093/cvr/cvs259. 
86. Civitarese, R.A.; Talior-Volodarsky, I.; Desjardins, J.F.; Kabir, G.; Switzer, J.; Mitchell, M.; Kapus, A.; McCulloch, C.A.; Gullberg, D.; Connelly, K.A. The $\alpha 11$ integrin mediates fibroblast-extracellular matrix-cardiomyocyte interactions in health and disease. American journal of physiology. Heart and circulatory physiology 2016, 311, H96-h106, doi:10.1152/ajpheart.00918.2015.

87. Carracedo, S.; Lu, N.; Popova, S.N.; Jonsson, R.; Eckes, B.; Gullberg, D. The fibroblast integrin $\alpha 11 \beta 1$ is induced in a mechanosensitive manner involving activin A and regulates myofibroblast differentiation. J Biol Chem 2010, 285, 10434-10445, doi:10.1074/jbc.M109.078766.

88. Lu, N.; Carracedo, S.; Ranta, J.; Heuchel, R.; Soininen, R.; Gullberg, D. The human $\alpha 11$ integrin promoter drives fibroblast-restricted expression in vivo and is regulated by TGF- $\beta 1$ in a Smad- and Sp1-dependent manner. Matrix Biol 2010, 29, 166-176, doi:10.1016/j.matbio.2009.11.003.

89. Romaine, A.; Sorensen, I.W.; Zeltz, C.; Lu, N.; Erusappan, P.M.; Melleby, A.O.; Zhang, L.; Bendiksen, B.; Robinson, E.L.; Aronsen, J.M.; et al. Overexpression of integrin $\alpha 11$ induces cardiac fibrosis in mice. Acta physiologica (Oxford, England) 2017, doi:10.1111/apha.12932.

90. Mould, A.P.; Askari, J.A.; Byron, A.; Takada, Y.; Jowitt, T.A.; Humphries, M.J. Ligand-induced epitope masking. Dissociation of integrin $\alpha 5 \beta 1$-fibronectin complexes only by monoclonal antibodies with an allosteric mode of action. J Biol Chem 2016, 291, 20993-21007, doi:10.1074/jbc.M116.736942.

91. Mould, A.P.; Craig, S.E.; Byron, S.K.; Humphries, M.J.; Jowitt, T.A. Disruption of integrin-fibronectin complexes by allosteric but not ligand-mimetic inhibitors. Biochem J 2014, 464, 301-313, doi:10.1042/BJ20141047.

92. Pihlajaniemi, T.; Myllyla, R.; Kivirikko, K. Prolyl 4-hydrox-ylase and its role in collagen synthesis. . J Hepatol 1991, 13, S2-7.

93. Friedman, S.L.; Neuschwander-Tetri, B.A.; Rinella, M.; Sanyal, A.J. Mechanisms of NAFLD development and therapeutic strategies. Nat Med 2018, 24, 908-922, doi:10.1038/s41591-018-0104-9.

94. Tamayo, R.P. Is Cirrhosis of the Liver Experimentally Produced by CCl4 an Adequate Model of Human Cirrhosis? Hepatology 1983, 3, 112-120.

95. Buitrago, L.; Zafar, H.; Zhang, Y.; Li, J.; Walz, T.; Coller, B.S. Dominant role of alphaIIbbeta3 in platelet interactions with cross-linked fibrin fragment D-dimer. Blood Adv 2020, 4, 2939-2949, doi:10.1182/bloodadvances.2020001545.

96. Sehr, T.; Proschmann, U.; Thomas, K.; Marggraf, M.; Straube, E.; Reichmann, H.; Chan, A.; Ziemssen, T. New insights into the pharmacokinetics and pharmacodynamics of natalizumab treatment for patients with multiple sclerosis, obtained from clinical and in vitro studies. J Neuroinflammation 2016, 13, 164, doi:10.1186/s12974016-0635-2.

97. Boziki, M.; Bakirtzis, C.; Giantzi, V.; Sintila, S.A.; Kallivoulos, S.; Afrantou, T.; Nikolaidis, I.; Ioannidis, P.; Karapanayiotides, T.; Koutroulou, I.; et al. Long-Term Efficacy Outcomes of Natalizumab vs. Fingolimod in Patients With Highly Active Relapsing-Remitting Multiple Sclerosis: Real-World Data From a Multiple Sclerosis Reference Center. Front Neurol 2021, 12, 699844, doi:10.3389/fneur.2021.699844.

98. Singh, S.; HassanMurad; Fumery, M.; Sedano, R.; VipulJairath; RemoPanaccione; JSandborn, W.; Ma, C. Comparative efficacy and safety of biologic therapies for moderate-to-severe Crohn's disease: a systematic review and network meta-analysis. The Lancet Gastroenterology E Hepatology 2021, doi:doi.org/10.1016/S24681253(21)00312-5.

99. Holland, E.J.; Jackson, M.A.; Donnenfeld, E.; Piccolo, R.; Cohen, A.; Barabino, S.; Rolando, M.; Figueiredo, F.C. Efficacy of Lifitegrast Ophthalmic Solution, 5.0\%, in Patients With Moderate to Severe Dry Eye Disease: A Post Hoc Analysis of 2 Randomized Clinical Trials. JAMA Ophthalmol 2021, doi:10.1001/jamaophthalmol.2021.3943.

100. Qin, Y.; Garrison, B.S.; Ma, W.; Wang, R.; Jiang, A.; Li, J.; Mistry, M.; Bronson, R.T.; Santoro, D.; Franco, C.; et al. A Milieu Molecule for TGF- $\beta$ Required for Microglia Function in the Nervous System. Cell 2018, 174, 156171 e116, doi:10.1016/j.cell.2018.05.027.

101. Takasaka, N.; Seed, R.I.; Cormier, A.; Bondesson, A.J.; Lou, J.; Elattma, A.; Ito, S.; Yanagisawa, H.; Hashimoto, M.; Ma, R.; et al. Integrin alphavbeta8-expressing tumor cells evade host immunity by regulating TGF-beta activation in immune cells. JCI Insight 2018, 3, doi:10.1172/jci.insight.122591.

102. Yu, Y.; Schurpf, T.; Springer, T.A. How natalizumab binds and antagonizes $\alpha 4$ integrins. J Biol Chem 2013, 288, 32314-32325, doi:10.1074/jbc.M113.501668. 
103. Bouvet, M.; Claude, O.; Roux, M.; Skelly, D.; Masurkar, N.; Mougenot, N.; Nadaud, S.; Blanc, C.; Delacroix, C.; Chardonnet, S.; et al. Anti-integrin $\alpha(v)$ therapy improves cardiac fibrosis after myocardial infarction by blunting cardiac PW1(+) stromal cells. Scientific reports 2020, 10, 11404, doi:10.1038/s41598-020-68223-8.

104. Alcaraz, L.B.; Exposito, J.Y.; Chuvin, N.; Pommier, R.M.; Cluzel, C.; Martel, S.; Sentis, S.; Bartholin, L.; Lethias, C.; Valcourt, U. Tenascin-X promotes epithelial-to-mesenchymal transition by activating latent TGF- $\beta$. J Cell Biol 2014, 205, 409-428, doi:10.1083/jcb.201308031. 